Pelagic Copepods from Kabira Bay, Ishigaki Island, Southwestern Japan, with the Description of a New Species of the Genus Pseudodiaptomus

AUTHOR(S):

Nishida, Shuhei

CITATION:

Nishida, Shuhei. Pelagic Copepods from Kabira Bay, Ishigaki Island, Southwestern Japan, with the Description of a New Species of the Genus Pseudodiaptomus. PUBLICATIONS OF THE SETO MARINE BIOLOGICAL LABORATORY 1985, 30(1-3): 125-144

ISSUE DATE:

1985-06-30

URL:

http://hdl.handle.net/2433/176098

RIGHT: 


\title{
Pelagic Copepods from Kabira Bay, Ishigaki Island, Southwestern Japan, with the Description of a New Species of the Genus Pseudodiaptomus
}

\author{
By \\ Shuhei Nishida \\ Ocean Research Institute, University of Tokyo, \\ 1-15-1, Minamidai, Nakano, Tokyo, 164, Japan
}

With Text-figures $1-8$ and Table 1

\begin{abstract}
Taxonomy and distribution of the pelagic copepods were investigated in Kabira Bay, Ishigaki Island. From the samples collected by vertical and oblique tows, 13 species of calanoids, eight species of cyclopoids and one species of harpacticoid were identified. A new species, Pseudodiaptomus ishigakiensis, and other little known species are described. Acartia bispinosa, A. fossae and Oithona dissimilis are firstly recorded in Japan. Distribution of the major copepod species shows that the hydrographic condition of the inner part of the bay is appropriate for the maintenance of neritic species, and oceanic species presumably cannot proliferate in the inner part of the bay.
\end{abstract}

Ishigaki Island, located at $24^{\circ} 20.7^{\prime} \mathrm{N}, 124^{\circ} 08.5^{\prime} \mathrm{E}$, east of Formosa, is among the southernmost islands of the Ryukyu Archipelago. Although the copepod fauna in the East and South China Seas (Mori, 1937; Chiba, 1949; Chen \& Zhang, 1965; Chen et al., 1974, etc.) and the water around Formosa (Tseng, 1970a, b) has been investigated in some details, nothing has been reported on the pelagic copepods in the embaymental waters of the Ryukyu Archipelago.

During 1975 1976, a plankton investigation was carried out in Kabira Bay, a small inlet on the northwestern coast of Ishigaki Island, as a part of a study on the coral-reef ecosystem (see Horikoshi, 1979, for a preliminary report). This paper reports some results of this investigation. An annotated list of pelagic copepods in Kabira Bay is presented together with the description of a new species of the genus Pseudodiaptomus. The distribution of the major copepod species is also described and discussed.

Samples were collected on 23 January and 9-10 June, 1975 and 22 October, 1976 at ten stations inside or outside Kabira Bay (Fig. 1). For convenience, these stations are grouped into three areas according to the topography of the bay: the embayment (Stns P2-P6), the waterway (Stns P8-P11) and the outside of the bay (Stns P12-P13). Collections were made in the daytime within one hour before and after high tides, although some of the stations in the waterway and outside the bay were omitted owing to the bad weather and strong current. At each station, plankton was collected by one or two vertical tows of a hand-towed net (23-cm mouth diameter, 40- $\mu \mathrm{m}$ mesh aperture) from the bottom to the surface. Additionally, oblique tows were made between the stations in the embayment (Stns P3-P4) and outside the bay (Stns P12-P13) to collect the less abundant species.

Publ. Seto Mar. Biol. Lab., 30 (1/3), 125-144, 1985.

(Article 5) 


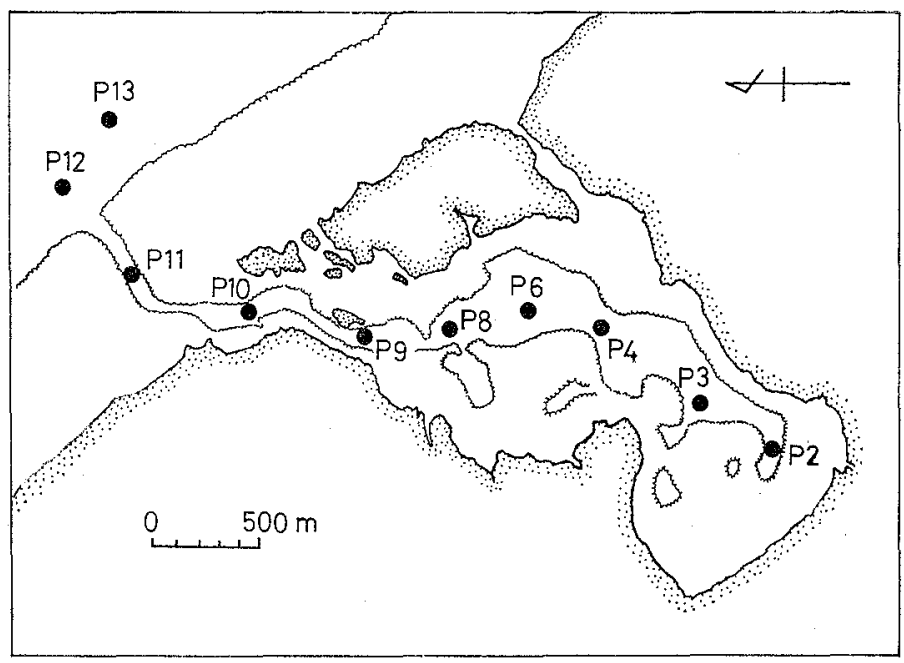

Fig. 1. Sampling stations.

The samples were fixed and preserved in $4 \%$ formaldehyde/seawater solution buffered with sodium tetraborate. In the vertical tows, the volume of water filtered was estimated by the mouth area of the net and the length of tow, assuming a 100\% filtration efficiency. In the laboratory, large animals such as chaetognaths, decapod larvae and larger copepods (about $1 \mathrm{~mm}$ or more in length) were first sorted out, identified and counted. From the rest of the sample, ten 1/100-subsamples were obtained by a Stempel pipette, and copepods were counted and identified in a covered Sedgwick-Rafter cell (4-ml capacity, 4-mm depth) under a compound microscope. Both immature copepodid stages and adults were identified. The specimens which required an intensive observation were sorted out, stained with methyl blue, dissected and examined under a compound microscope. Drawings were made with the aid of a camera lucida.

\section{Annotated List of Pelagic Copepods in Kabira Bay}

\section{Order Calanoida}

Family Calanidae

Undinula vulgaris (Dana, 1849)

Undina vulgaris Dana, 1849, p. 22.

Calanus vulgaris. -Giesbrecht, 1892, p. 92, pl. 6, fig. 11, pl. 7, figs. 2, 24, 27, pl, 8, figs. 17, 35.

Undinula vulgaris. -A. Scott, 1909, pl. 6.

OCGURRENGE. Stn P8, 22 Oct., 1976, 1 female.

\section{Family Paracalanidae}

\section{Paracalanus sp.}

OCCURRENGE. Stns P3-P4, 10 June, 1975, 1 female.

Remarks. The length of the present specimen is $0.80 \mathrm{~mm}$. The numbers of the teeth on the proximal outer margin of the third exopodal segment of the legs 
2-4 are 9-10,14 and 16-19, respectively. These characteristics agree with those of $P$. parvus f. minor described by Tanaka (1956). Bowman (1971) examined the specimens of $P$. parvus group off the southeastern United States and distinguished two species, $P$. quasimodo and $P$. indicus, which had been identified as $P$. parvus by the previous workers. This suggests that Japanese specimens which have been identified as $P$. parvus may be distinct from $P$. parvus or include species endemic to the Pacific. Further examination is necessary to solve this problem.

\section{Paracalanus aculeatus Giesbrecht, 1888}

Paracalanus aculeatus Giesbrecht, 1888, p. 333; 1892, p. 164, pl. 9, figs 20, 26, 30.

OCGURRENCE. Stn P4, 23 Jan., 1975, 2 females.

Paracalanus crassirostris (Dahl, 1894)

Paracalanus crassirostris Dahl, 1894, p. 12, pl. 1, figs 27-28. -Tanaka, 1960, p. 23, pl. 6, figs 1-7. -Chen \& Zhang, 1965, p. 41, pl. 9, figs 1-6. -Wellershaus, 1969, p. 247, figs 1-9.

Paracalanus crassirostris f. typica Fruchtl, 1923, p. 456; 1924, p. 36.

Paracalanus crassirostris var. nudus Davis, 1944, p. 4, pls 1-2.

Parvocalanus crassirostris. --Andronov, 1970, p. 984. - -Hiromi, 1981, p. 155, figs 1-2.

OCGURRENCE. See Fig. 7.

Remarks. Wellershaus (1969) listed the known forms of $P$. crassirostris on the basis of the marginal spinules on the exopods of female legs 2-4. In the present specimens ( 4 females), the third exopodal segments of female legs $2-4$ have 4-5, $7-11$ and 7-10 spinules on the proximal outer margin, respectively, and none on the distal margin. These characteristics are similar to those of $P$. crassirostris $f$. typica (Früchtl, 1923) and P. crassirostris var. nudus (Davis, 1944).

Acrocalanus similis Sewell, 1914

Acrocalanus similis Sewell, 1914, p. 211, figs 3-5. -Wellershaus, 1969, p. 253, figs 10-20.

OCCURRENCE. Stns P3-P4, 10 June, 1975, 2 females.

$$
\begin{gathered}
\text { Family Calocalanidae } \\
\text { Calocalanus pavo (Dana, 1849) }
\end{gathered}
$$

Calanus pavo Dana, 1849, p. 13.

Galocalanus pavo. -Giesbrecht, 1892, p. 175, pl. 1, fig. 13, pl. 14, fig. 15, pl. 9, figs 3, 4, 13, 19, pl. 36, figs $43-45$.

OGGURRENGE. Stn P6, 10 June, 1975, 1 female.

Family Clausocalanidae

Clausocalanus arcuicornis (Dana, 1849)

Calanus arcuicornis Dana, 1849, p. 12.

Clausocalanus arcuicomis. -Frost \& Fleminger, 1968, p. 46, figs 29-33.

OCGURRENCE. Stn P2, 23 Jan., 1975, 1 female. 
Drepanopus furcatus Brady, 1883, p. 77, pl. 4, figs 1-2, pl. 24, figs 12-15.

Clausocalanus furcatus. -Frost \& Fleminger, 1968, p. 76, pls 64-67.

OCGURRENGE. Stn P3, 23 Jan., 1975, 2 females.

\section{Family Centropagidac}

Centropages sp.

OCGURRENCE. Stns P3-P4, 10 June, 1975, 2 immature females.

Family Pseudodiaptomidae

\section{Pseudodiaptomus ishigakiensis, new species}

(Figs 2-4)

Material. Specimens were collected on 23 Jan., 1975 by an oblique net tow between Stns P3 and P4. Types are deposited in the National Science Museum, Tokyo (NSMT), and the National Museum of Natural History, Smithsonian Institution (USNM). Holotype, 1 female (NSMT-Cr 8684); allotype, 1 male (NSMT-Cr 8685); paratypes, 15 females and 10 males (NSMT-Gr 8686), 5 females and 8 males (USNM 213187).

Female: Total length $1.20-1.29 \mathrm{~mm}$ (holotype, $1.24 \mathrm{~mm}$ ). Cephalothorax length $0.74-0.79 \mathrm{~mm}$ (holotype, $0.77 \mathrm{~mm}$, measured from the anterior to posterior middorsal margins of cephalothorax, Fig. 2a); width 0.35-0.38 mm (holotype, $0.37 \mathrm{~mm}$ ).

Head rounded in dorsal view. Rostrum produced into 2 long filaments. Cephalosome and first thoracic segment separate; fourth and fifth thoracic segments fused. Fifth thoracic segment symmetrical; posterior corners produced into small spiniform processes. Proportional lengths of abdominal segments and caudal ramus 32.2: 14.8: 18.4: 11.6: 23.0; length to width ratios $1.4,0.95,1.2,0.76$ and 4.0. First to third abdominal segments each with row of triangular spinules on dorsoposterior margin; size of spinules increasing from first to third segments. Genital segment produced ventrally, slightly asymmetrical in dorsal view; dorsal surface with a few medial, transverse rows of very fine spinules; ventral surface with transeverse row of spinules anterior to genital area, a pair of fine setae near posterior margin. Lateral outer margin of caudal ramus divided into 4 portions (proportions of anterior to posterior portions $2: 2: 1: 1)$ by 2 small notches and base of lateral seta.

First antenna (Fig. 2e) length 1.2 times cephalothorax; 22-segmented; each segment except segments $6,15,16,18-20$ with aesthete; segments 6-7 incompletely fused, the former with short spine; segment 20 having specialized seta with small teeth on medial margin. Second antenna (Fig. 2f). Basal segment with 1 proximal, 2 medial and 2 distal outer marginal setae; expood with 7 terminal and 8 subterminal setae, and lateral fringe of fine hairs. Endopod 4-segmented; third segment inconspicuous and looking like membrane connecting second and fourth segments; first segment with 1 seta; second segment with 1 proximal, 2 medial and 1 terminal setae; third segment with 1 seta; fourth segment with 2 proximal, 1 medial and 3 terminal 


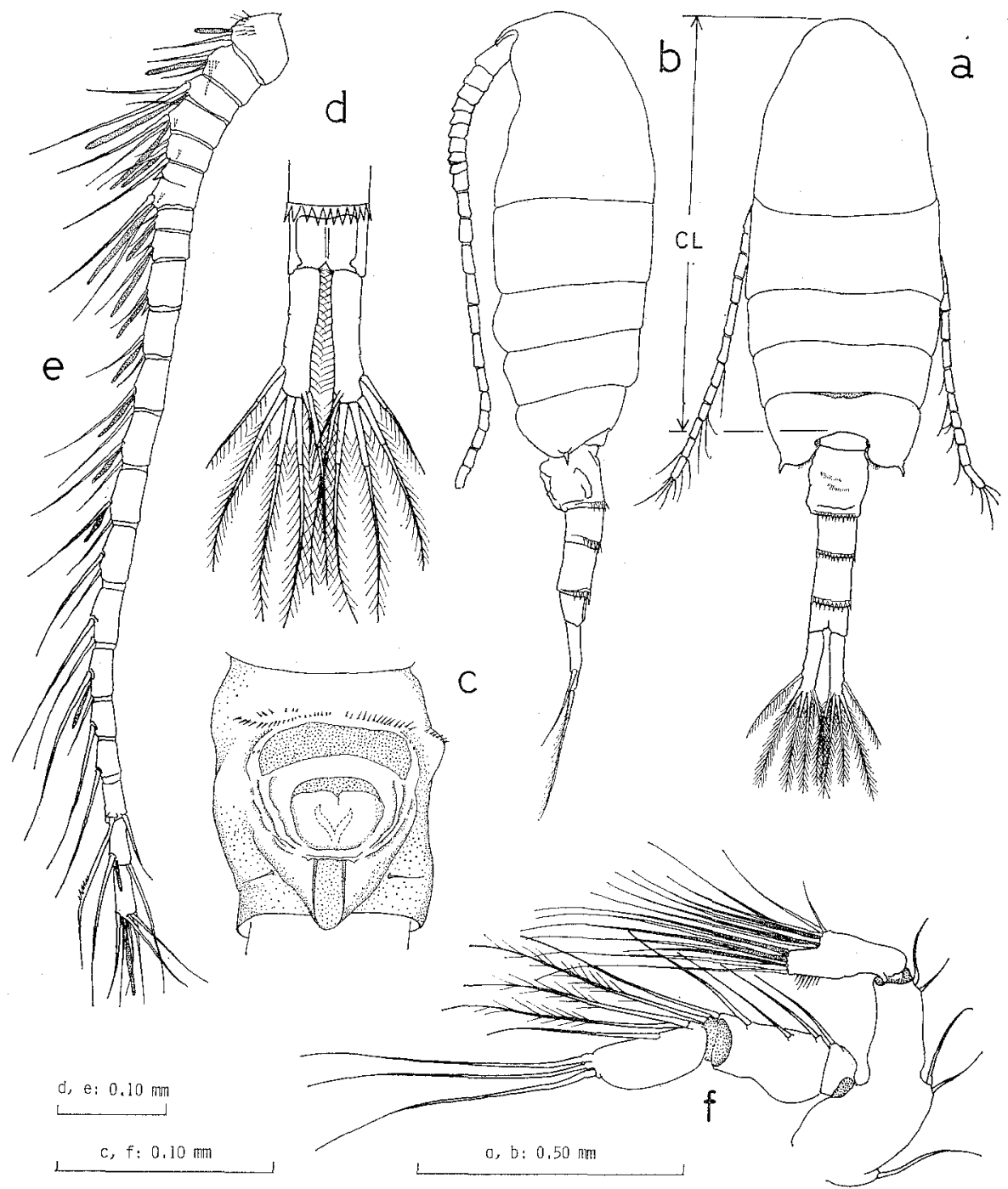

Fig. 2. Pseudodiaptomus ishigakiensis n. sp. Female: a, whole animal, dorsal view; b, whole animal, lateral view; c, genital segment, ventral view; d, anal segment and caudal rami, dorsal view; e, right first antenna, ventral view; $f$, second antenna. CL: cephalothorax length.

setae. Mandible (Fig. 3a). Basal segment of palp with 4 inner marginal setae. Exopod inconspicuously 2-segmented; proximal segment with 5, terminal segment with 8 setae and row of spinules on surface. Endopod with 6 setae; segmentation incomplete. First maxilla (Fig. 3b). Gnathobase with 9 strong and 2 finer spines; anterior surface with row and patch of spinules. Second and third inner lobes each with 4 terminal setae. Outer lobe with 7 long and 2 short setae. Exopod with 10 marginal setae. Endopod incompletely 3-segmented; first to third segments with 4, 4, and 7 setae, respectively. Second maxilla not examined. Maxilliped (Fig. 3c) 6segmented; 2 basal segments large, 4 distal segments small. Setation as in Fig. 3c. 


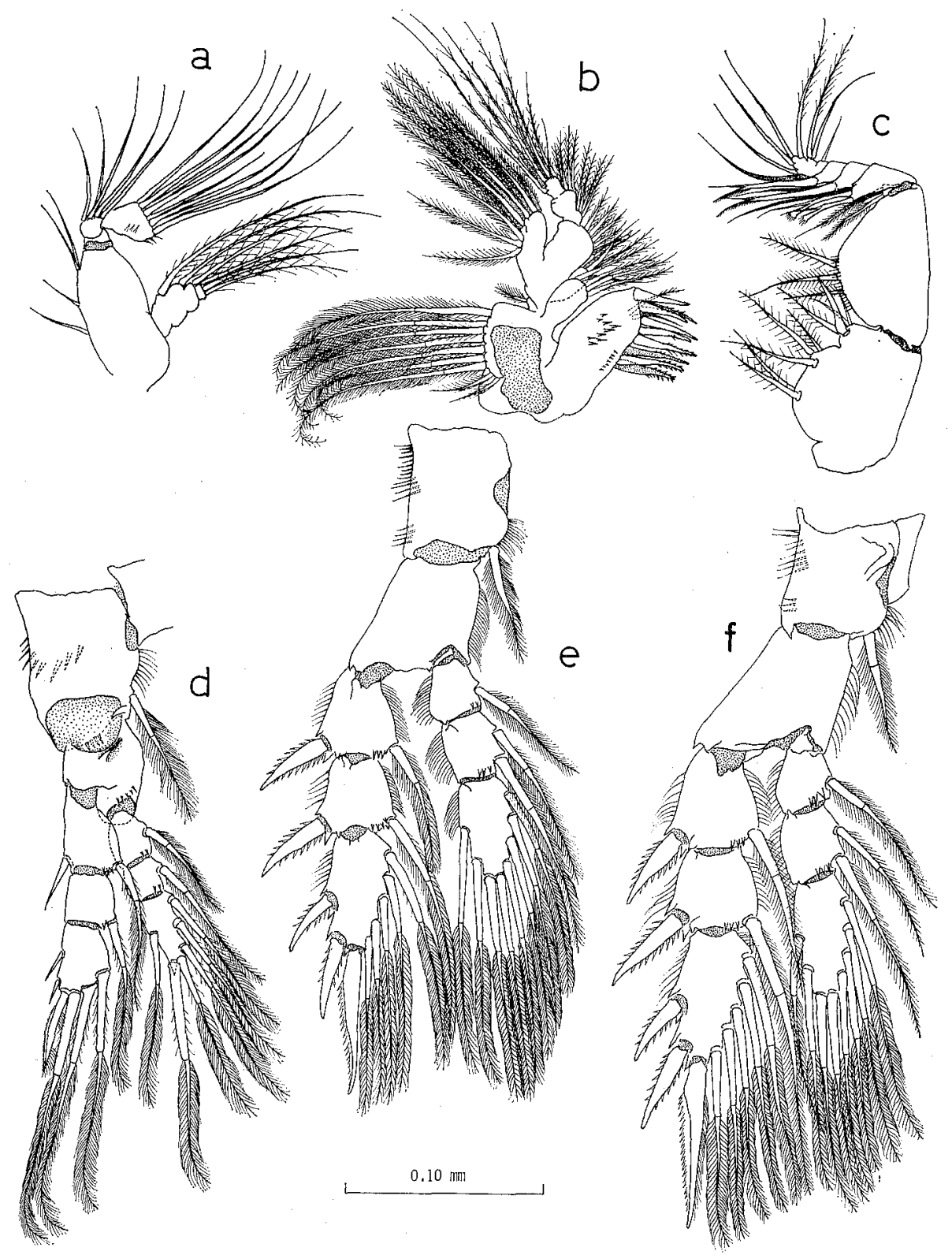

Fig. 3. Pseudodiaptomus ishigakiensis n. sp. Female: a, mandible; b, first maxilla; c, maxilliped; $\mathrm{d}, \operatorname{leg} 1 ; \mathrm{e}, \operatorname{leg} 2 ; \mathrm{f}, \operatorname{leg} 3$.

Legs 1-4 (Figs. 3d-f, 4a) biramous, with 2 basal segments and 3-segmented exopod and endopod. First and second segments of both exopod and endopod of legs 1-3 with spinules on inner distal margin; only leg 4 with seta on second segment. Other spines and setae as in Figs. 3d-f and $4 \mathrm{a}$.

Leg 5 (fig. 4b) uniramous, 4-segmented and symmetrical; second segment, unlike P. marinus Sato, 1913 (Grindley \& Grice, 1969; present observation), without 


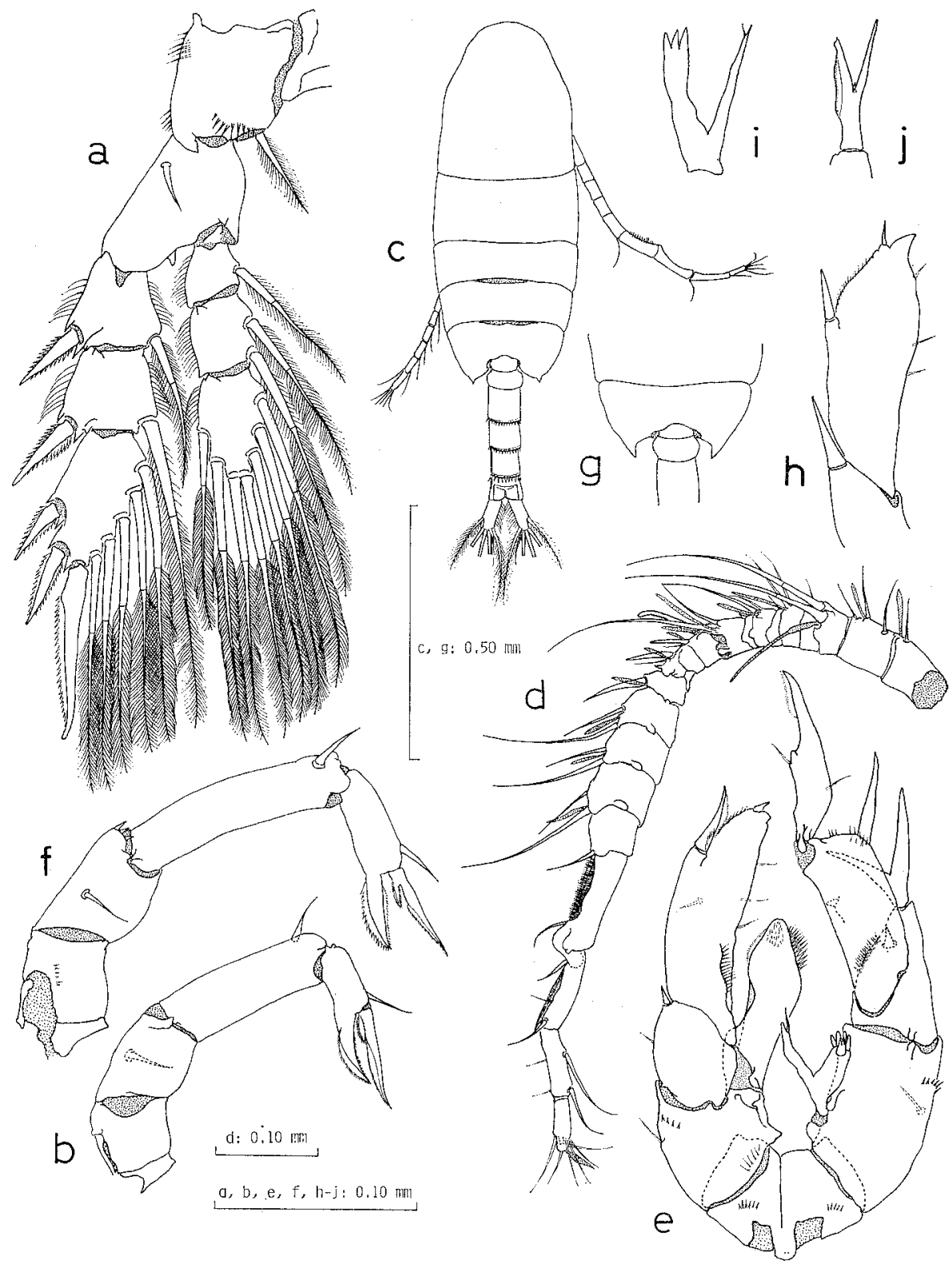

Fig. 4. Pseudodiaptomus ishigakiensis n. sp. Female: a, leg 4; b, leg 5. Male: c, whole animal, dorsal view; d, right first antenna, ventral view; e, leg 5. Pseudodiaptomus marinus from Hokkaido. Female: f, leg 5. Male: g, fifth thoracic segment, dorsal view; h, leg 5, left exopod; $i$, leg 5, right endopod; $j$, leg 5, Y-shaped spine on first segment of right exopod.

spinules on outer distal margin; third segment length 3.2 times width, with outer distal seta. Fourth segment with outer distal seta; inner distal part produced distally into curved spiniform process with serrate membrane on both margins; terminal 
spine with teeth on distal half of inner margin, and short serrate spine near its base.

Male: Total length 1.01-1.05 mm (allotype, $1.04 \mathrm{~mm}$ ). Cephalothorax length $0.65-0.68 \mathrm{~mm}$ (allotype, $0.67 \mathrm{~mm}$, measured from the anterior to posterior middorsal margins of cephalothorax); width $0.29-0.31 \mathrm{~mm}$ (allotype, $0.30 \mathrm{~mm}$ ).

Cephalothorax as in female. Proportional lengths of abdominal segments and caudal ramus 9.0: 20.2: 17.9: 17.6: 15.7: 19.6; length to width ratios $0.4,1.0,1.1$, $1.1,0.8$ and 2.8. Second to fourth abdominal segments each with row of triangular spinules on whole posterior margin; the size of spinules increasing from second to fourth segments.

Appendages similar to female except right first antenna and leg 5. Right first antenna 21-segmented; seta and spines as in Fig. 4d.

Leg 5 biramous, with 2 basal segments, 2-segmented exopod and 1-segmented endopod. First basal segment with row of spinules on anterior surface. Second basal segment with medial outer seta and distal outer row of spinules. First segment of right expod with row of spinules on inner margin, on distal end with $\mathrm{V}$-shaped bifurcated spine without spinule in the fork; a little proximally to its base with short thick spinule. Second exopodal segment with long, straight naked spine on outer distal margin, and short thick spinule on posterior surface near medial point of inner margin; terminal hook with 1 inner and 1 outer midmarginal setae. Right endopod bifurcate; inner ramus slender and pointed, with fine seta near distal end; outer ramus thick and with 5 blunt distal spinules, one with teeth on tip. First segment of left expood with short naked spine on outer distal corner. Second segment with short terminal spine, and thick long outer spine with serrate membrane on inner margin; outer margin between these spines fringed with tiny spinules; inner margin with 3 fine setae distally, and row of setules proximally; 1 fine seta on medial posterior surface. Left endopod with patch of spinules on posterior surface near distal end, row of setules on distal inner margin, and serrate membrane on distal outer margin.

Remarks. Pseudodiaptomus ishigakiensis is distinguished from the closely allied species, $P$. marinus and $P$. ardjuna Brehm, 1953, in the following characters. (1) The spiniform processes on the fifth thoracic segment are smaller than in $P$. marinus (Fig. $4 \mathrm{~g}$ ) in both sexes. (2) The second segment of female leg 5, unlike P. marinus, lacks spinules on the distal outer margin; the third segment is thicker than in $P$. marinus (Fig. 4f). (3) The spiniform process on the fourth segment of female leg 5 is much more finely serrated on the medial margin than in P. marinus. (4) The first segment of the right expod of the male leg 5 has a $V$-shaped terminal spine, and there is no spinule in the fork; the homologous spine is $\mathrm{Y}$-shaped in P. marinus and $P$. ardjuna; in $P$. marinus there is a spinule in the fork, and the inner margin of the inner ramus is modified into a blade-like thin membrane (Fig. 4j); in $P$. ardjuna (Brehm, 1953, Fig. 81; Pillai, 1970, Fig. $1 \mathrm{~m}$ ) one of the branch is much shorter than the other. (5) Right endopod of male leg 5 has five terminal spinules on the outer ramus; the homologous ramus has two to four points in $P$. ardjuna (Pillai, 1970, 
Fig. $1 \mathrm{~m}$ ) and $P$. marinus (Grindley \& Grice, 1969; Fig. 4i). (6) The first segment of the left expood of male leg 5 has a much shorter outer marginal spine than in $P$. marinus (Fig. 4h) and P. ardjuna (Brehm, 1953, Fig. 82; Pillai, 1970, Fig. 1m). (7) The outer marginal spine on the second exopodal segment of the left exopod of male leg 5 is long, extending beyond the tip of the terminal spine; the homologous spine is shorter in $P$. marinus (Fig. $4 \mathrm{~h}$ ). (8) In the male leg 5, the spine at the base of the forked spine on the first segment of right expod is much shorter than in P. marinus.

Grindley \& Grice (1969) noted marked difference among the specimens of $P$. marinus collected from Mauritius, Japan and Hawaii, and the previous descriptions of $P$. marinus, especially in the right exopod and the forked spine on male leg 5 , and the spine at the base of the forked spine. They considered that these differences do not indicate even subspecific differenciation, and might reprseent ecophenotypes. To examine the distinctiveness between $P$. ishigakiensis and $P$. marinus, I observed the specimens of $P$. marinus from Hokkaido (Nemuro Bay, collected by the Plankton Laboratory, Hokkaido University), Tokyo Bay (collected by the author), Seto Inland Sea (collected by S. Uye) and Kyushu (Ariake Bay, collected by R. Hirota). The differences between $P$. ishigakiensis and $P$. marimus in all the characters mentioned above were proved to be constant for all the above localities including Grindley \& Grice's description of the specimens from Mauritius, and it is concluded that $P$. ishigakiensis is a species distinct from $P$. marinus.

Family Parapontellidae

Neopontella typica A. Scott, 1909

Neopontella typica A. Scott, 1909, p. 185, pl. 55, figs 1-15.

OCCURRENGE. Sin P4, 22 Oct., 1976, 1 female and 1 male.

Family Acartiidae

Acartia bispinosa Carl, 1907

(Fig. 5)

Acartia bispinosa Carl, 1907, p. 13, pl. 1, figs 1-2. -Grice, 1964, p. 261, figs 35-37.

? Acartia tokiokai Mori, 1942, p. 556, p1. 11, figs 1-18.

Acartia hamata Wilson, 1950, p. 152, pl. 2, figs 1-5.

OCCURRENCE. Stns P3-P4, 10 June, 1975, 5 females; Stns P12-P13, 10 June, 1975, 1 male.

Female: Distal corners of fifth thoracic segment produced into strong spiniform processes, each with small spine a little dorsally and medially, and a fine setule more dorsally. Posterior margin of genital segment with a pair of small spines dorsolaterally. Caudal ramus with transverse row of setules on dorsal surface. First segment of first antenna with 2 strong spines produced distally from anterior distal margin, with smaller spine near base of these spines; second segment with strong clawlike spine curving proximally from midposterior margin. Terminal segment of leg 5 length 2.4 times width: terminal spine slender, with finely serrated 


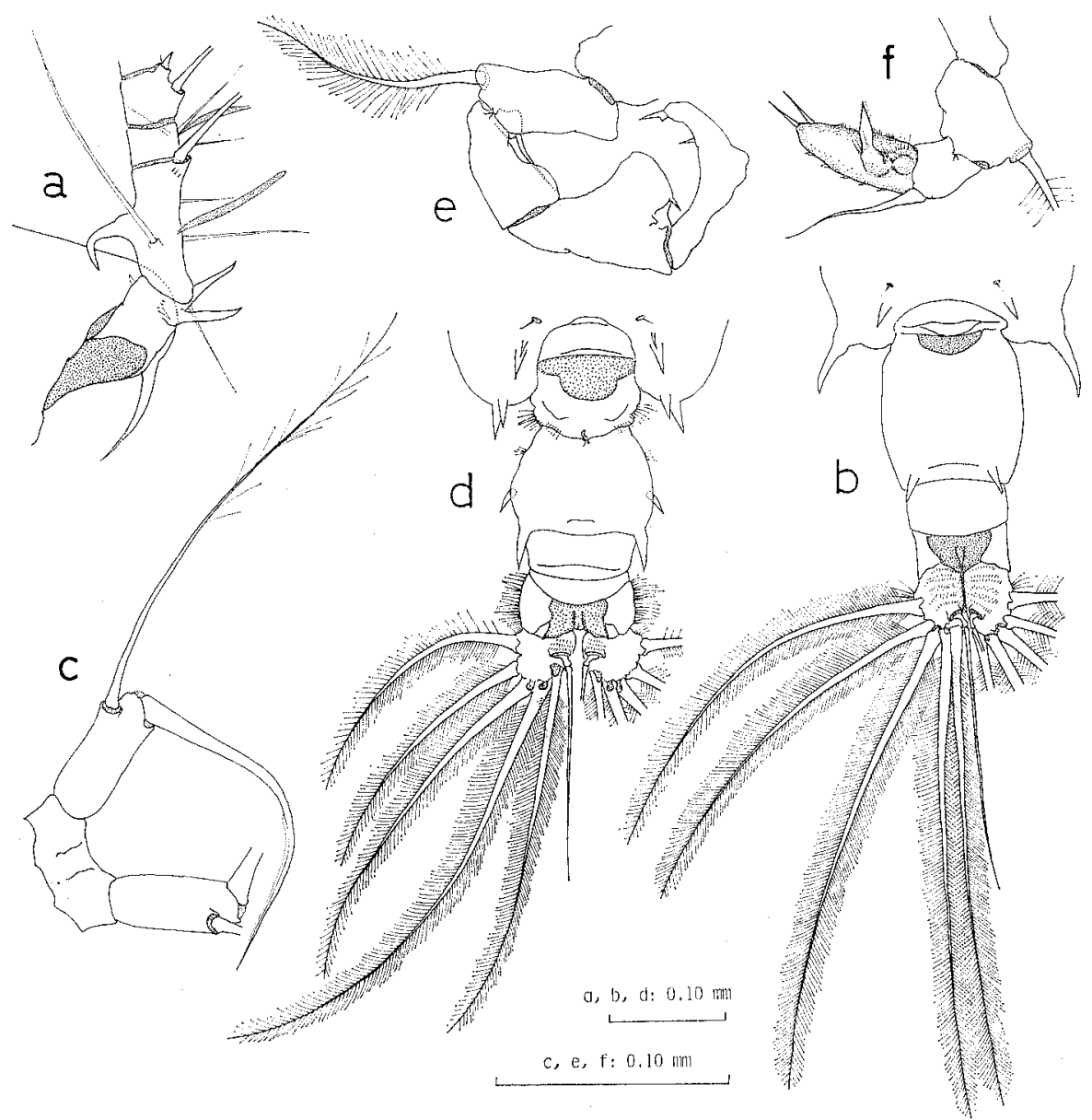

Fig. 5. Acartia bispinosa. Female: a, rostrum and first antenna, lateral view; b, fifth thoracic segment and abdomen, dorsal view; c, leg 5. Male: $d$, fifth thoracic segment and abdomen, dorsal view; e, right leg $5 ; f$, left leg 5 .

membrane on distal third.

Male: Posterior corners of fifth thoracic segment each with 2 subequal spines, dorsolaterally with 2 spines, one very small, and a fine setule more dorsally. First abdominal segment with rows of short hairs on lateral and posterior margins; second segment with tuft of hairs on anterior lateral surface, and a pair of small spines on ventrolateral side; posterior margin produced dorsolaterally into a pair of strong spiniform processes. Caudal ramus with transverse rows of setules at base of inner dorsal seta. Terminal segment of left leg 5 with 2 fine terminal spines, stout spine on midanterior surface with fine setae on its base, tuft of hairs proximal to the medial spine, row of spinules along inner margin, and several spinules along outer margin.

Remarks. Acartia bispinosa has been reported from Indonesia (Carl, 1907), Persian Gulf (Pesta, 1912), Sri-Lanka (Sewell, 1914), Seychells (Gianferrari, 1921, 
1923), Gilbert Islands and Fiji Islands (Wilson, 1950) and presumably from Australia (Dakin \& Colefax, 1940) and Palao (Mori, 1942; see Grice, 1964). This is the first record of $A$. bispinosa in Japan and may be the northernmost record in the Pacific.

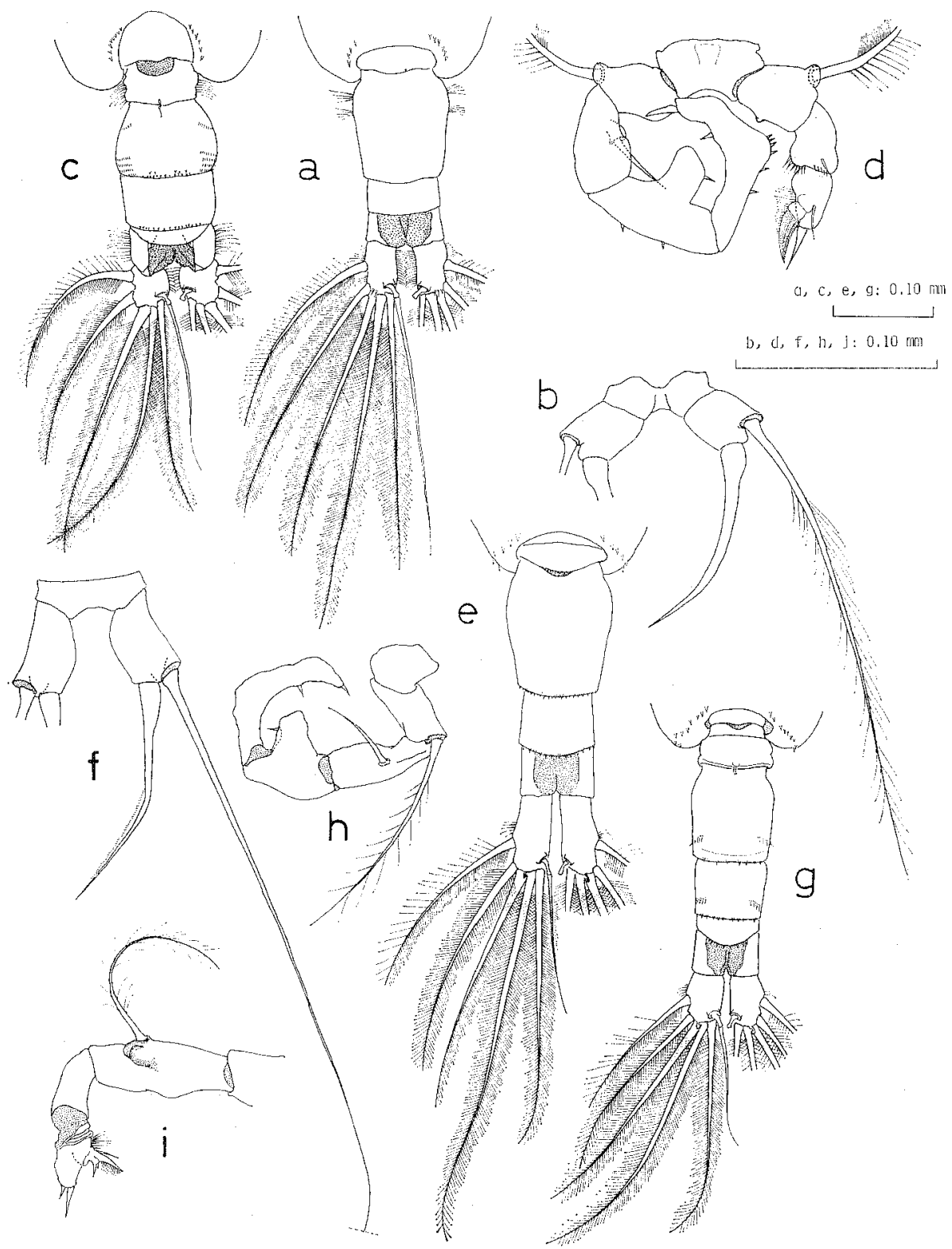

Fig. 6. Acartia fossae. Female: a, fifth thoracic segment and abdomen, dorsal view; b, leg 5 . Male: c, fifth thoracic segment and abdomen, dorsal view; d, leg 5 . Acartia steueri. Female: e, fifth thoracic segment and abdomen, dorsal view; $f$, leg 5 . Male: g, fifth thoracic segment and abdomen, dorsal view; h, right leg 5 ; i, left leg 5 . 
Acartia fossae Gurney, 1927

(Figs 6a-d)

Acartia fossae Gurney, 1927, p. 156, figs 22a-f. -Grice, 1964, p. 262, figs 38-40.

? Acartia hamata Mori, 1937, p. 104, pl. 51, figs 1-5; 1942, p. 555, pl. 10, figs 1-2.

OCCURRENCE. See Fig. 8.

Female: Fifth thoracic segment with row of spinules on dorsoposterior margin. Genital segment with 2 pairs of lateral tufts of hairs on anterior portion. Caudal ramus with dorsal spinules near base of outer terminal seta. Terminal segment of leg 5 nearly square; terminal spine swollen near its base, length about 0.5 times outer seta; terminal segment with small process between outer seta and terminal spine.

Male: Fifth thoracic segment with row of spinules on dorsoposterior margin. First abdominal segment with hair tufts on lateral margin. Second abdominal segment with dorsolateral rows of setules on medial and posterior portions. Second to fourth abdominal segments with rows of spinules on posterodorsal margin. Second segment of left leg 5 with fine seta near outer distal margin, and 2 rows of setules on inner distal margin and midanterior surface of distal margin; terminal segment with terminal spine thick and naked, 1 modified spine and 1 seta on midanterior surface; inner margin with row of fine hairs. The modified spine appears to be fringed on its outer margin with a row of setules or a thin membrane.

Remarks. Acartia fossae has been reported from the Suez Canal (Gurney, 1927), Tuamotu Islands (Vaissière, 1954) and Nosy-Bé (Binet \& Dessier, 1968). The present record from Ishigaki Island which is located between the East China Sea near Amamioshima Island and Palao, where A. hamata has been reported by Mori (1937, 1942), supports the opinion of Grice (1964) that A. fossae and A. hamata may be conspecific.

Acartia steueri Smirnov, 1936

(Figs 6e-i)

Acartia steueri Smirnov, 1936, p. 87, figs 1-3. -Brodsky, 1948, p. 75, pl. 25, figs 7-8, pl. 26, fig. 1. Tanaka, 1965, p. 388, fig. 245.

OCGURRENCE. See Fig. 7.

Female: Fifth thoracic segment with row of spinules on posterior margin. First and seocnd abdominal segments with spinules on dorsoposterior margin. Length of terminal segment of leg 51.8 times width; outer seta long, length 4 times terminal spine; terminal spine swollen at its base, with finely serrated membrane on distal half of inner margin.

Male: Fifth thoracic segment with row of spinules on posterior margin. Second to fourth abdominal segments with spinules on dorsoposterior margin. Second and third abdominal segments each with a pair of ventrolateral rows of spinules near 
posterior margin; second segment with or without a pair of ventral spinules near anterior margin. First segment of left leg 5 with protuberance on midanterior surface near base of outer seta. Terminal segment with 2 naked terminal spines, 1 strong spine produced inward from proximal inner margin with tuft of hairs on its proximal side, spine and seta at its base, and row of short hairs on outer margin.

Remarks. In the present specimens, the two ventral spinules on the second abdominal segment of the male described by Tanaka (1965) were present in some but absent in the others, and the presence of these spinules is considered variable even within a local population. Acartia steueri has been reported from the northern part of the Sea of Japan (Brodsky, 1948), the southern Kuriles (Kos, 1958), the Izu Region, Central Japan (Tanaka, 1965) and northern Kyushu (Ueda, 1980). This is the southernmost record of this species.

Acartia erythraea Giesbrecht, 1889

Acartia erythraea Giesbrecht, 1889, p. 26; 1892, p. 508, pl. 30, figs 5, 19, 32, pl. 43, figs 1, 7, 12-15.

OCGURRENCE. See fig. 7.

\section{Order Cyclopoida \\ Family Oithonidae}

Oithona plumifera Baird, 1843

Oithona plumifera. -Giesbrecht, 1892, p. 537, pl. 34, figs 12-13, 22, 25, 27-29, 32-33, 44-47, pl. 44, figs $1,7,12-15$.

OCCURRENCE. Stn P6, 23 Jan., 1975, 2 females; Stn P10, 22 Oct., 1976, 1 female.

Oithona similis Claus, 1866

Oithona similis Claus, 1866, p. 14. - Giesbrecht, 1892, p. 537, pl. 34, figs 18, 19, 21, 36-39, pl. 44, figs $3,5,8-11$.

OGGURRENCE. See Fig. 8.

Oithona nana Giesbrecht, 1892

Oithona nana Giesbrecht, 1892, p. 538, pl. 34, figs 10-11, 20, 24, 34-35, 42, pl. 44, figs 2, 4, 6.

OCGURRENGE. See Fig. 8.

Oithona aruensis Früchtl, 1923

Oithona brevicornis f. aruensis Frücht1, 1923, p. 454; 1924, p. 88, figs 44 (1)--(2), table 7.

Oithona aruensis. -Nishida \& Ferrari, 1983, p. 74, figs $2-5$.

OCGURRENCE. See Fig. 7.

Remarks. The detailed description of $O$. aruensis, the diagnosis of this species and closely allied $O$. brevicornis and $O$. wellershausi, and related synonymies are given in Ferrari (1981) and Nishida \& Ferrari (1983). 


\title{
Oithona attenuata Farran, 1913
}

Oithona attenuata Farran, 1913, p. 187, pl. 30, figs 3-7.

OCCURRENCE: Stn P6, 23 Jan., 1975, 1 female.

Oithona oculata Farran, 1913

Oithona oculata Farran, 1913, p. 188, pl. 30, fig 8-9, pl. 31, figs $2-9$.

OCCURRENGE: See Fig. 8.

Oithona simplex Farran, 1913

Oithona simplex Farran, 1913, p. 187, pl. 29, figs 10-14, pl. 30, figs 1-2.

OCCURRENCE. See Fig. 7.

Oithona dissimilis Lindberg, 1940

Oithona dissimilis Lindberg, 1940, p. 520, fig. 2. -Ferrari, 1977, p. 400, figs 1A-G, 2A-E, 3A-B. Oithona dissimilis oceanica Lindberg, 1947, p. 52, figs $2 \mathrm{a}-\mathrm{j}$.

Oithona hebes Giesbrecht. -Wellershaus, 1969, p. 276, figs 88-102.

OGCURRENCE. See Fig. 8.

Remarks. This is the first record of $O$. dissimilis in Japan and the northernmost record in the Pacific.

\section{Order Poecilostomatoida \\ Family Oncacidae}

Oncaea spp.

OCGURRENGE. Stns P2, P3, P6, P8, 23 Jan., 1975, 26 specimens; Stns P8, P10, P11, 22 Oct., 1976,19 specimens.

\section{Family Corycaeidae \\ Corycaeus spp.}

OCCURRENCE. Stn P3, 23 Jan., 1975, 1 specimen; Stns P6, P8, P9, P10, 22 Oct., 1976, 4 specimens.

\author{
Order Harpacticoida \\ Family Ectinosomatidae \\ Microsetella rosea (Dana, 1848)
}

Harpacticus roseus Dana, 1848 , p. 153.

Microsetella rosea. -Giesbrecht, 1892, p. 550, pl. 44, figs 32, 35, 37, 38, 41, 43, 46, 48, 49.

OCCURRENCE. Stn P12, 9 June, 1975, 2 females.

\section{Distribution of the Major Copepod Species}

Table 1 shows the order of abundance of the dominant copepods in the 
embayment. In all three months, the copepod fauna in Kabira Bay was dominated by the three genera, Paracalanus, Acartia and Oithona, which accounted for more than $90 \%$ of the total number of copepods. Distribution of the major copepod species is shown in Figs. 7-8.

Paracalanus crassirostris was the most abundant species; its maximum density reached $25000 / \mathrm{m}^{3}$ in January and June. In these months the density was highest in

Table 1. Major copepod species in Kabira Bay.

The figures in the parentheses indicate the percentage of each species of the total number of copepods (combined mean of Stns P2, P3, P4 and P6)

\begin{tabular}{lll}
\hline \multicolumn{1}{c}{ Jan., 1975} & \multicolumn{1}{c}{ June, 1975} & \multicolumn{1}{c}{ Oct., 1976} \\
\hline Paracalanus crassirostris $(92.2)$ & O. aruensis $(48.1)$ & P. crassirostris $(55.1)$ \\
Acartia erythraea $(4.5)$ & P. crassirostris $(44.3)$ & O. simplex $(27.1)$ \\
Oithona aruensis $(1.6)$ & O. simplex $(5.5)$ & O. aruensis $(12.4)$ \\
Acartia steueri $(0.5)$ & A. fossae $(0.9)$ & O. dissimilis $(2.2)$ \\
Oithona dissimilis $(0.3)$ & O. oculata $(0.4)$ & \\
\hline
\end{tabular}
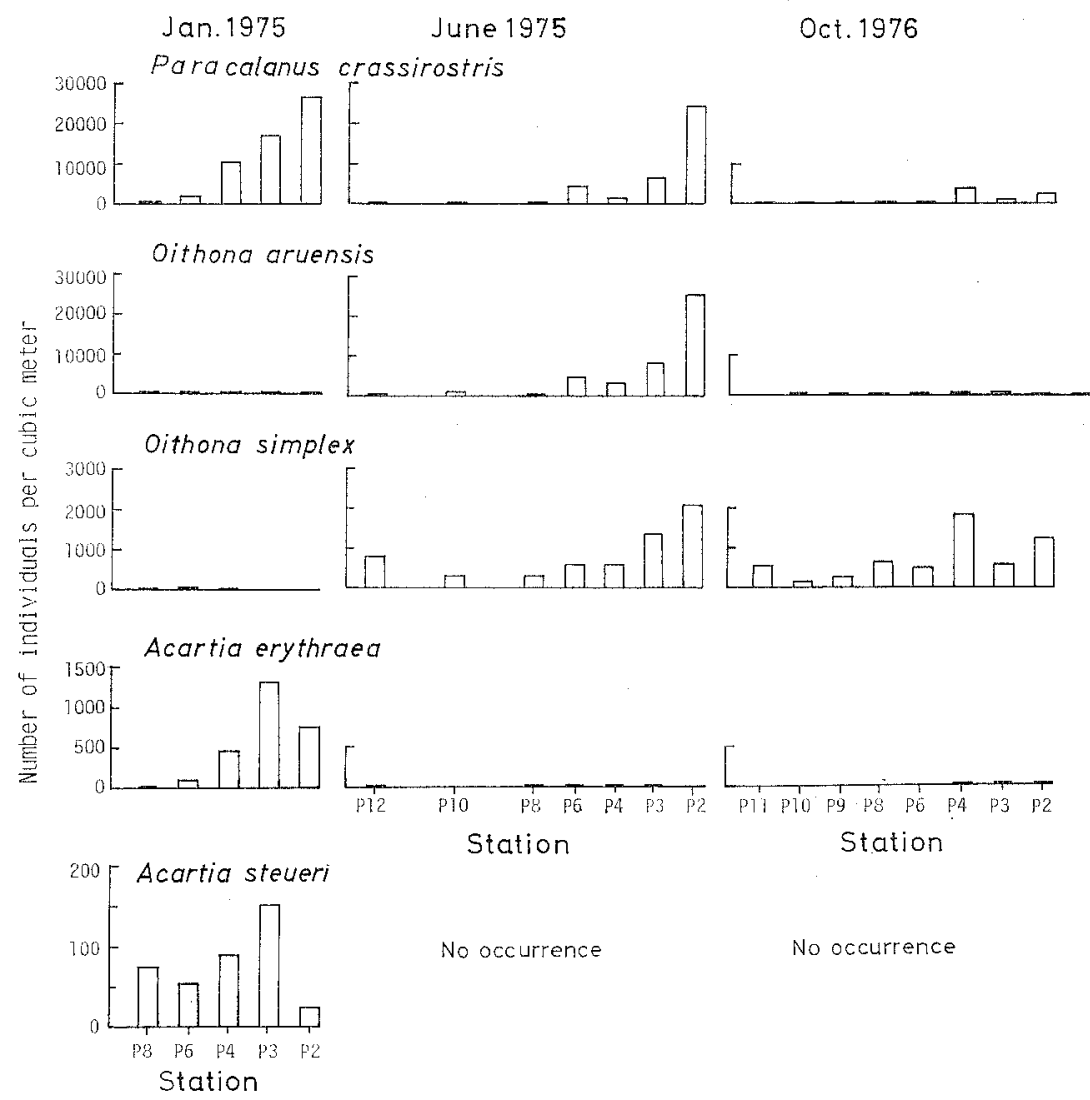

No occurrence No occurrence

Fig. 7. Distribution of Paracalanus crassirostris, Oithona aruensis, O. simplex, Acariia erythraea and A. steueri in Kabira Bay. 


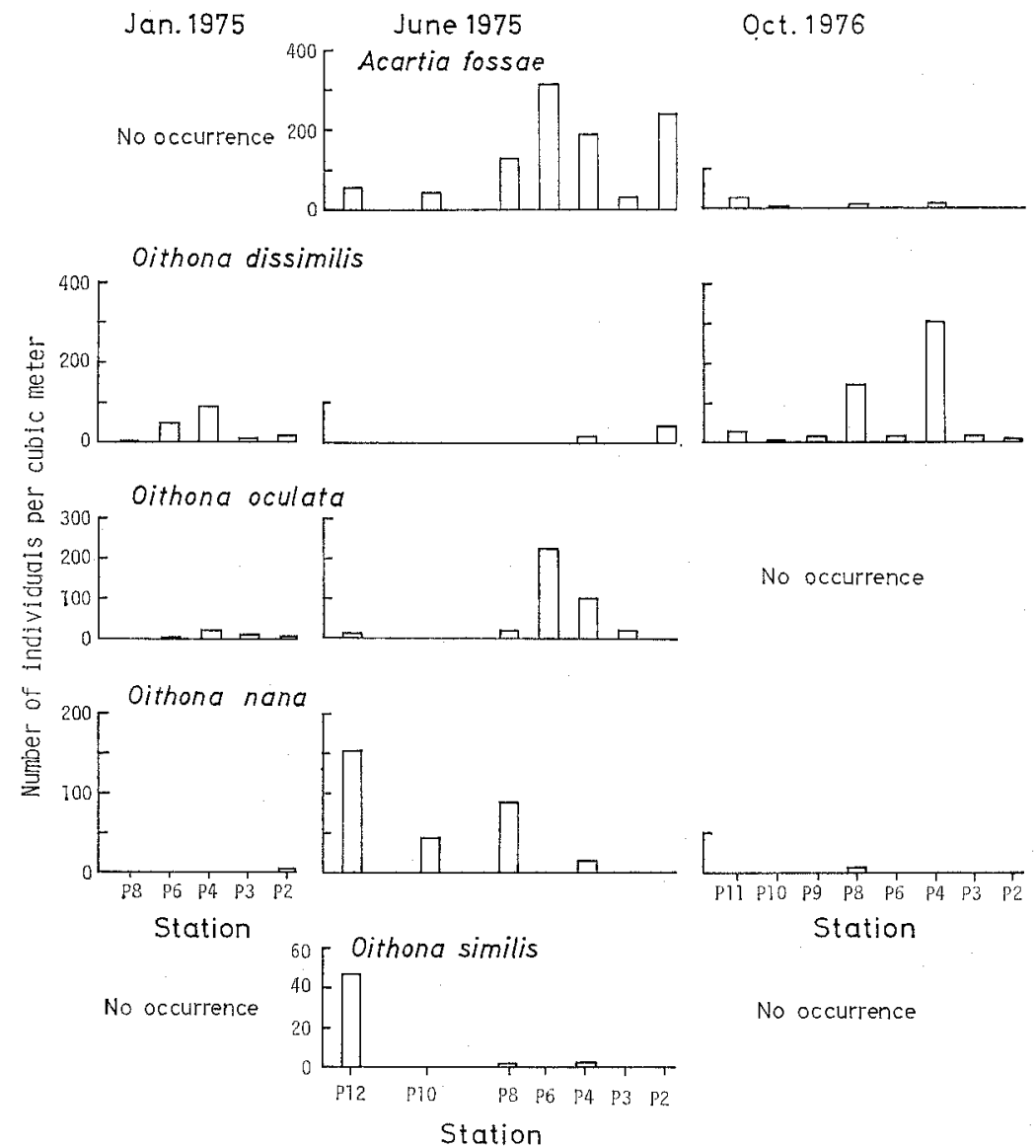

Fig. 8. Distribution of Acartia fossae, Oithona dissimilis, $O$. oculata, $O$. nana and $O$. similis in Kabira Bay.

the innermost part of the bay. In October when the density was much lower than in the other two months, the decrease of density from the inner to the outer stations was less marked.

Oithona aruensis was abundant in June, making up $48 \%$ of the total copepods, but was scarce in January and October. The pattern of distribution of $O$. aruensis resembles that of $P$. crassirostris. In June when $O$. aruensis was abundant, its density increased markedly from the outer to the innermost stations, whereas the differences of densities among stations were small in January and October.

Oithona simplex was abundant in June and October, but was scarce in January. Although this species had its center of distribution in the inner part of the bay, the difference of densities between the inside and outside of the bay was smaller than in $P$. crassirostris and $O$. aruensis.

Acartia erythraea was abundant in January, the highest density being $1300 / \mathrm{m}^{3}$. Though it occurred in higher densities in the embayment than in the waterway and outside the bay, unlike $P$. crassirostris and $O$. aruensis, the density decreased from Stn 
P3 to the innermost Stn P2.

Acartia steueri occurred in January, A. fossae in June and October, and $O$. dissimilis in all the three months, though in low densities. These three species did not show any characteristic patterns of distribution except that they were more abundant in the embayment than in the waterway and outside the bay.

Oithona oculata occurred in low densities in January and June, showing a tendency to increase in the center of the embayment.

Oithona nana and $O$. similis showed high densities outside the bay in June, decreasing through the waterway towards the embayment. In the other two months, these two species and $O$. plumifera and $O$. attenuata occurred in low densities only in the waterway and/or outside the bay.

\section{Discussion}

In Japanese embaymental waters north of Kyushu, Acartia clausi, Paracalanus parvus and Oithona aruensis are among the most abundant pelagic copeods (Yamazi, 1956; Hirota \& Hara, 1975; Itoh \& Iizuka, 1979; Ueda, 1980, etc.). In Kabira Bay, however, only $O$. aruensis of these three species occurred in significant numbers; the other two species were not collected in the present study, except for a single specimen which resembles $P$."parvus ( $P$. sp.). The paracalanid fauna in Kabira Bay is characterized by the dominance of Paracalanus crassirostris, while the acartiid fauna is characterized by the alternate occurrence of $A$. steueri, $A$. fossae and $A$. bispinosa; the latter two species have not been reported north of Kyushu. The number of the species of neritic Oithona is also larger in Kabira Bay than in the northern waters owing to the co-occurrence of $O$. simplex and $O$. dissimilis with $O$, aruensis and $O$.oculata; only the latter two are the typical neritic species in the waters north of Kyushu (Itoh \& Iizuka, 1979; Ueda, 1980). Thus, the copepod fauna in Kabira Bay differs from that in the embaymental waters of Japan north of Kyushu in having a different species composition and larger number of species, showing a characteristic of the equatorial-neritic waters.

Hydrographically, Kabira Bay is under a strong influence of the oceanic water introduced into the bay, although it is isolated from the open sea by the wide fringing reef with the exception of a narrow waterway; about $68 \%$ of the bay water is estimated to be exchanged with the water outside the bay in 4.5 days (Horikoshi, 1979). In the present study, however, a great abundance of several species which are known to proliferate in embaymental conditions was observed in the inner part of the bay.

The pelagic copepods in Kabira Bay can be divided into three groups according to their patterns of distribution: (1) species which are distributed pirncipally in the embayment and whose density increases towards the innermost part ( $P$. crassirostris, $O$. aruensis); (2) species which are distributed principally in the waterway and outside the bay and are almost absent in the embayment (O. similis, O. nana); (3) species which are abundant in the embayment but do not show significant increase 
of density in the innermost part (A. erythraea, A. steueri, A. fossae, O. simplex, O. oculata, $O$. dissimilis). The existence of the distribution pattern shown by Group-(1) indicates that the hydrographic condition in the innermost part of Kabira Bay, in spite of the strong oceanic inflow, is appropriate for the maintenance of the population of the neritic species, while that shown by Group-(2) indicates that the individuals of the oceanic species introduced into the embayment are numerically insignificant as members of the embaymental zooplankton community and presumably cannot reproduce in the inner part of the bay.

\section{Acknowledgements}

I would like to express my sincere thanks to Dr. R. Marumo, Nodai Research Institute, who gave me the opportunity to make this study, and to Dr. T.E. Bowman, Smithsonian Institution, who reviewed the manuscript. Special thanks are due to Dr. Y. Aruga, Tokyo University of Fisheries, Dr. T. Ishimaru, Ocean Research Institute, and the members of the Yaeyama Branch of the Okinawa Prefectural Fisheries Experimental Station for their kind help in collecting samples. Thanks are also due to the Plankton Laboratory, Hokkaido University, Dr. S. Uye, Hiroshima University, and Dr. R. Hirota, Kumamoto University, who kindly provided me with the specimens of Pseudodiaptomus marinus from various localities in Japan.

\section{References}

Andronov, V.N. 1970. Some problems on taxonomy of the family Paracalanidae (Copepoda). Zool. Zhur., 49: 980-985.

Binet, D., \& A. Dessier. 1968. Zooplankton de la région de Nosy-Bé. III. Premiéres données sur les copépodes. Cah. O.R.S.T.O.M., ser. Océanogr., 6: 3-26.

Bowman, T.E. 1971. The distribution of calanoid copepods off the southeastern United States between Cape Hatterass and South Florida. Smiths. Cont. Zool., No. 96, 58 pp.

Brady, G.S. 1883. Report on the Copepoda collected by H.M.S. Challenger during the years 187376. Rep. Voy. Challenger 1873-76, Zool., 8: 1-142.

Brehm, V. 1953. Indische Diaptomiden, Pseudodiaptomiden und Cladoceren. Ost. zool. Zs., 4: 241-345.

Brodsky, K.A. 1948. Free-living copepod crustaceans (Copepoda) of the Sea of Japan. Izv. tikhookean. nauchno-issled. Inst. ryb. Khoz. Okeanogr., 26: 3-130. (In Russian)

Carl, J. 1907. Copepodes d'Amboine. Revue suisse Zool., 15: 7-18.

Chen, Q., \& S. Zhang. 1965. The planktonic copepods of the Yellow Sea and the East China Sea. I. Calanoida. Stud. mar. Sinica, No. 7: 20-131.

Chen, Q., S. Zhang \& C. Zhu. 1974. On planktonic copepods of the Yellow Sea and the East China Sea. II. Cyclopoida and Harpacticoida. Stud. mar. Sinica, No. 9:27-76.

Chiba, T. 1949. On the distribution of the plankton in the Eastern China Sea and the Yellow Sea. I. Plankton composition in spring. J. Shimonoseki Coll. Fish, 1:57-64.

Claus, G. 1863. Die Freilebenden Copepoden mit besonderen Beruicksichtigung der Fauna Deuthchlands, der Nordsee und des Mittelmeeres. Leipzig, 230 pp., 37 pls.

-1866. Die Copepoden-Fauna von Nizza. Ein Beitrag zur Charakteristik der Formen und deren Abänderungen "im Sinne Darwin's". Marburg and Leipzig, 34 pp., 5 pls.

Dahl, F. 1894. Die Copepodenfauna des unteren Amazones. Ber. naturf. Ges. Freiburg i Br., 8: 10-23, pl. 1.

Dakin, W.J., \& A.N. Colefax. 1940. The plankton of the Australian coastal waters off New South Wales, Pt. 1. Monogr. Dep. Zool. Univ. Sydney, 1: 1-215.

Dana, J.D. 1848. Conspectus Crustaceorum, in orbis terrarum circumnavigatione, C. Wilkes e 
classe Reipublicae Faederatae duce, collectorum auctore J.D. Dana. Pars I. Proc. Amer. Acad. Arts Sci, 1: 149-155.

- 1849. Conspectus Grustaceorum quae in orbis terrarum circumnavigatione, Carolo Wilkes e Classe Reipublicae Federatae duce, lexit et descripsit Jacobus D. Dana, Pars II. Proc. Amer. Acad. Arts Sci., 2: 9-61.

Davis, G.C. 1944. On four species of Copepoda new to Chesapeake Bay, with a description of a new variety of Paracalanus crassirostris Dahl. Contr. Chesapeake biol. Lab., No. 61: 1-11.

Farran, G.P. 1913. Plankton from Christmas Island, Indian Ocean, II: On Copepoda of the genera Oithona and Paroithona. Proc. zool. Soc. Lond., 1913: 181-193.

Ferrari, F.D. 1977. A redescription of Oithona dissimilis Lindberg, 1940, with a comparison to Oithona hebes Giesbrecht, 1891 (Crustacea, Copepoda, Cyclopoida). Proc. biol. Soc. Wash., 90: 400411 .

- 1981. Oithona wellershausi, new species, and O. spimulosa Lindberg, 1950 (Copepoda: Cyclopoida: Oithonidae) from the mouth of the Pearl River, China. Proc. biol. Soc. Wash., 94: 1244-1257.

Frost, B., \& A. Fleminger. 1968. A revision of the genus Clausocalanus (Copepoda: Calanoida) with remarks on distributional patterns in diagnostic characters. Bull. Scripps Inst. Oceanogr., 12: $1-235$.

Frücht1, F. 1923. Cladoceren und Copepoden der Aru-Inseln (vorlaufige Mitteilung: Artenliste und Kurze Diagnosen der neuen Formen). Abh. senckenb. naturforsch Ges., 37: 449-457.

-2 - 1924. Die Cladoceren- und Copepoden-Fauna des Aru-Archipels. Mit Beitragen zur Kenntnis der strukturellen Anomalien indopazifischer Planktoncopepoden. Arb. zool. Inst. Univ. Innsbruck, 2: 25-136.

Gianferrari, L. 1921. Le Acartie della spedizione "Valdivia". Natura, Milano, 12: 14-30.

-.__ 1923. Die Acartien der deutschen Tiefsee-Expedition. Arb. zool. Inst. Univ. Innsbruck, 1: 75-87.

Giesbrecht, W. 1888. Elenco dei Copepodi pelagici raccolti dal tenente di vascello Gaetano Chierchia durante il viaggio della R. Corvetta "Vettor Pisani" negli anni 1882-1885 e dal tenente di vascello Francesco Orsini nel Mar Rosso, nel 1884. Atti Accad. naz. Lincei, Rend. 4, 4 (2): 330-338.

- 1892. Systematic und Faunastik der pelagischen Copepoden des Golfes von Neapel. Fauna Flora Golf. Neapel, vol. 19, 831 pp., 54 pls.

Grice, G.D. 1964. Two new species of calanoid copepods from the Galapagos Islands with remarks on the identity of three other species. Crustaceana, 6:255-264.

Grindley, J., \& G.D. Grice. 1969. A redescription of Pseudodiaptomus marinus Sato (Copepoda, Calanoida) and its occurrence at the Island of Mauritius. Crustaceana, 16: 125-134.

Gurney, R. 1927. Zoological results of the Cambridge Expedition to the Suez Canal, 1924. VIII. Report on the Crustacea: Copepoda and Cladocera of the Plankton. Trans. zool. Soc. Lond., 22: 139-172.

Hiromi, J. 1981. Three species of paracalanid copepods in the neighbouring waters of Japan. Bull. Plankton Soc. Japan, 28: 153-164.

Hirota, R., \& M. Hara. 1975. Zooplankton investigations in Yatsushiro-kai, western Kyushu, I. Regional and seasonal occurrences of the important zooplankton. J. Oceanogr. Soc. Japan, 31: 115-123.

Horikoshi, M. 1979. Coastal marine ecosystem in the tropical region: Kabira Cove, Ishigaki Island, as a model of physiographic unit of regional ecosystem. In: Environmental Marine Science III (ed. Horibe, Y.), pp. 145-169, Univ. Tokyo Press, Tokyo. (In Japanese)

Itoh, H., \& S. Iizuka. 1979. Studies on the zooplankton in Omura Bay-I. Seasonal Occurrence of Copepods. Bull. Fac. Fish. Nagasaki Univ., 47: 5-14.

Kos, M.S. 1958. Some data on the coastal planktonic Copepoda from South-Kuril Bay. Dokl. Akad. Nauk SSSR, 120: 191-192. (In Russian)

Lindberg, K. 1940. Cyclopoides (Crustaces Copepodes) de l'Inde. Rec. Indian Mus., 42: 519-526. $47-55$ 
Mori, T. 1937. The Pelagic Copepoda from the Neighbouring Waters of Japan. Tokyo, 140 pp., $80 \mathrm{pls}$.

-. 1942. Systematic studies of the plankton organisms occurring in Iwayama Bay, Palao. IV. Copepoda from the Bay and adjacent waters. Palao trop. biol. Stn Stud., 2: 549-580.

Nishida, S., \& F.D. Ferrari. 1983. Redescription of Oithona brevicornis Giesbrecht and O. aruensis Fruchtl, new rank, with notes on the status of O. spinulosa Lindberg. Bull. Plankton Soc. Japan, 30: 71-80.

- O. Tanaka \& M. Omori. 1977. Cyclopoid copepods of the family Oithonidae in Suruga Bay and adjacent waters. Bull. Plankton Soc. Japan, 24: 119-158.

Pesta, O. 1912. Wissenschaftliche Ergebnisse der Expedition nach Mesopotamien. Crustaceen. I. Teil: Copepoden aus dem Golf von Persien. Annln naturh. Mus. Wien, 26: 39-62.

Pillai, P.P. 1970. Pseudodiaptomus jonesi, a new calanoid copepod from Indian waters. Curr. Sci., 39: $78-80$.

Sato, T. 1913. Pelagic copepods. I. Bull. Hokkaido Fish. experimental Station, vol. 1, 79 pp., 8 pls. (In Japanese)

Scott, A. 1909. The Copepoda of the Siboga Expedition. Part I. Free swimming, littoral and semi-parasitic Copepoda. Siboga Exped., 29A: 1-323.

Sewell, R.B.S. 1914. Notes on the surface Copepoda of the Gulf of Manner. Spolia zeylan., 9: 191-262.

Smirnov, S. 1936. Beschreibung einer neuen Acartia-Art aus dem Japanischen Meer nebst einiger Bemerkungen uber die Untergattung Euacartia Steuer. Zool. Anz., 114: 87-92.

Tanaka, O. 1956. The pelagic copepods of the Izu Region, middle Japan. Systematic account II. Families Paracalanidae and Pseudocalanidac. Publ, Seto mar. biol. Lab., 5: 367-406.

- 1960. Pelagic Copepoda. Spec. Publ. Seto mar. biol. Lab., No. 10, 95 pp., 40 pls.

- 1965. The pelagic copepods of the Izu Region, middle Japan. Systematic account XIII. Families Parapontellidae, Acartiidae and Tortanidae. Publ. Seto mar. biol. Lab., 12: 379-409.

Tseng, W.Y. 1970a. On Copepoda of the family Candaciidae in the northeast sea-waters of Taiwan, pp. 245-249. In Proc, of the 2nd CSK Symposium, Tokyo, 1970 (ed. Sugawara, K.). Saikon Publ. Co. Ltd., Tokyo.

- 1970b. The zooplankton community in the surface waters of Taiwan Strait, pp. 261271. In Proc. of the 2nd CSK Symposium, Tokyo, 1970 (ed. Sugawara, K.). Saikon Publ. Co. Ltd., Tokyo.

Ueda, H. 1980. Zooplankton investigation in Shijiki Bay-I. Composition of zooplankton and distribution of copepods from April to August, 1975. Bull. Seikai Reg. Fish. Res. Lab., No. 54: 171-194.

Vaissiére, R. 1954. Description de Acartia (Acanthacartia) ransoni Rose 1953, Copepode pelagique des lagons des Iles Tuamotu. Bull. Mus. natn. Hist. nat., Paris, Ser. 2, 26: 358-362.

Wellershaus, S. 1969. On the taxonomy of planktonic Copepoda in Cochin Backwater (a South Indian estuary). Veröff. Inst. Meeresforsch. Bremerh., 11:245-286.

Wilson, G.B. 1950. Copepods gathered by the United States Fisheries Steamer "Albatross" from 1887 to 1909, chiefly in the Pacific Ocean. Bull. U.S. natn. Mus., 14: 141-441.

Yamazi, I. 1956. Plankton investigation in inlet waters along the coast of Japan. XIX. Regional characteristics and classification of inlet waters based on the plankton communities. Publ. Seto mar. biol. Lab., 5: 157-196.

Notes added in proof: For recent information of the taxonomic problems in Oithona aruensis and related species in Japan, see Nishicla et al. (1977), Nishida \& Ferrari (1983) and Nishida (in press).

Nishida, S. (In press). Taxonomy and distribution of the family Oithonidae (Copepoda, Cyclopoida) in the Pacific and Indian Oceans. Bull. Ocean Res. Inst., Univ. Tokyo, 20. 